\title{
Implementing the Net Zero Energy Building "nZEB" Strategies on an Existing Administration Building in Egypt
}

\author{
Moataz Osama El-Sherif ${ }^{\text {a }}$, Ayman Mohamed ${ }^{\text {a }}$, Mohamed Fatouh ${ }^{\text {a,b }}$
}

a. Mechanical Power Engineering Department, Faculty of Engineering at ElMattaria, Helwan University, Masaken El-Helmia P.O., Cairo 11718, Egypt.

b. High Institute for Engineering and Technology-Obour, k21 Cairo/Belbies Rd, Egypt.

\begin{abstract}
According to sustainable development strategy, the Egyptian government objective is reducing the energy consumption and greenhouse gas emissions by $14 \%$ and $10 \%$ respectively by 2030 . So, the national trend and the target of this phase is reducing the energy consumption in the buildings sector by applying the Net Zero Energy Building (NZEB) strategies to the new buildings and refurbishment the existing buildings to reduce the demand and apply on-site generation to reach NZEB target.

This study starts with the analysis of the current situation of an exemplary existing administrative building in Cairo, Egypt. Consequently, the economic feasibility of converting exemplary existing administrative to be nearly and Net ZEB is analyzed. Generally speaking, the guideline to achieve this has three steps; (1) reducing the energy consumption by suggesting retrofitting strategies, (2) implementing energy efficiency technologies, (3) installing energy generation systems. OpenStudio as a cross-platform collection of software tools used to build the model where it is simulated by EnergyPlus as an energy modeling engine. The energy consumption is validated by comparing it with the real energy consumption of the existing building.

The study analyzes the energy consumption including space heating, cooling, ventilation, lighting and appliances. The aforementioned guideline is applied by suggesting retrofitting strategy, implementing energy efficiency technologies instead of an existing one (11.925\% Energy reduction), then installing photovoltaic solar system as a renewable energy system (29.45\% Energy reduction). The
\end{abstract}


economic feasibility is evaluated. The research completes with a possible energy saving by applying nearly and net ZEB guidelines to the existing administration buildings. The final conclusion of the study is a method that merges both retrofitting the building and installing renewable energy systems that suit the Egyptian situation and possible to convert the existing administration buildings to nearly and net ZEB. 


\section{Introduction}

The current challenges of our society, decision makers and researchers are definitely directed towards an improvement in environmental sustainability, which extends to energy consumption, carbon emissions and water usage. The increasing energy consumption and the accompanied greenhouse gas emissions are considered one of the greatest concerns recently. The total electricity demand in Egypt for the year 2018 reached $131.15 \mathrm{TWh}$ with an annual average growth rate of $4.12 \%$. The building sector alone contributes with 68\% of total electricity demand in 2018 [1]. The energy is considered as the main pillar for the achievement of sustainable development, it is strongly affected by all economic, political and security issues faced by the country.

In MENA region, the proposed energy saving strategies were applied on cases to develop the building regulations and energy codes [2-4]. The National Energy Efficiency Action Plan (NEEAP) in Egypt targets to apply 3 steps to reduce electrical energy consumption: efficient lamps (LED), efficient appliances and the encouragement to use solar water heaters [5]. GPRS (Green pyramid rating system) was developed for Egypt as a national environmental rating system for buildings but it is not certified yet [6].

According to the large proportion which the buildings acquired. it was important to providing a model using buildings simulation tool and making sensitivity analysis to reduce the electric power consumption on peak hours [7]. Existing buildings represent the actual urban context, it participates with a significant share in the current energy problem. A survey including 1500 apartments in three governments in Egypt showed that all the surveyed buildings suffered from poor thermal performance and indoor air quality [8]. These numbers give a sense of the severity of energy performance of buildings in Egypt. The important step firstly is to decrease the waste of energy by applying an efficient and economically passive strategies $[9,10]$. In Egypt, the shading, window glazing, air tightness and insulation can reduce energy consumption of an average of 33\% [11].

In New Borg El Arab City, the high investment in the solar panels could be achieve a negative final energy balance [12]. Solar panels could be used also in a hybrid renewable energy system to achieve a net zero energy village in Alexandria [13]. The feasibility of Appling nZEBs as a proposed solution for the energy problem in Egypt was discussed for new design buildings [12]. The NZEB converting for residential buildings using local market materials and PV panels was found to be affordable [14].

In hot climate, nearly zero energy building could be achieved in existing building in Kuwait by installing High performance air conditioning system and integrating efficient PV modules [15] also, in Saudi Arabia (KSA) [16]. The cooling and power generation is the most effective parameters to be study which could be reach the net 
zero energy existing institutional building in hot climates [17]. Otherwise, using PV and parabolic trough collectors could be a suitable option after applying passive strategies to building to achieve NZEB [18].

In Egypt, the different whether regions were studied on residential flat in Cairo, Alexandria and Aswan [19]. The evaluation criteria of NZEB was discussed according to the European regulations and based on the annual balance of energy [20]. For NZEB evaluation, the research object and technology boundary could be clarified. The application of life cycle assessment (LCA) was discussed in NZEB evaluation [21].

According to these researches, the national trend and the target of this phase is going to reduce the energy consumption in the buildings sector by applying the NZEB strategies to the new buildings and refurbishment the already existing buildings to reduce the demand and apply on-site generation to reach NZEB target. According to sustainable development strategy (Egypt vision 2030 - Second Pillar) [22] the objective of the Egyptian government is to reduce energy consumption and greenhouse gas emissions by $14 \%$ and $10 \%$ respectively by the end of 2030 .

\subsection{Research Methodology}

After making a lot of investigation to find a suitable case study for an administration building in Cairo and overcoming all the obstacles to collect the building statistics and processing it to achieve the possibility of using it. the next step was coming, spending a lot of time to simulate that large building by the simulation platform to achieve the most similar model to the actual case. The clarification with the actual case was coming later to be sure that the simulated model is acceptable.

Studying the building from the architecture and energy point of views was necessary to propose the passive measures to reduce the energy consumption of the building. The orientation, Glazing, Shading and insulations were studied in different values and shapes to detect the effect of these measures on the energy consumption. Also, the active measures were applied by changing the lighting fixtures and propose different fixture types to achieve the most energy consumption reduction available.

After all these studies, the optimized model was created. Then installing photovoltaic solar system as a proposed renewable energy system. The economic feasibility is evaluated for all steps of the guideline. The research completes with a possible energy saving by applying nearly and net ZEB guidelines to the existing administration buildings. To get a method that merges both retrofitting the building and installing renewable energy systems that suit the Egyptian situation and possible to convert the existing administration buildings to nearly and net ZEB. 


\subsection{Selected Building Overview}

The building owner is Ministry of communication and information technology. With total floor area $25,000 \mathrm{~m}^{2}$ divided to $7^{\text {th }}$ floors. The total conditioned areas are $19,342 \mathrm{~m}^{2}(77.4 \%)$ otherwise the unconditioned areas are 5,658 $\mathrm{m}^{2}$ (22.6\%). The building consists of basement, ground and four typical floor plans. The building height is $28.5 \mathrm{~m}$. The building location is in Maadi smart village between $29^{\circ} 58^{\prime} 19^{\prime \prime}$ N, $31^{\circ} 17^{\prime} 00^{\prime \prime}$ E. Near Laselky St. and Autostrad as per Figure 1. The case study boundary includes the total building and the parking area beside the building $(1,537$ $\mathrm{m}^{2}$ ).

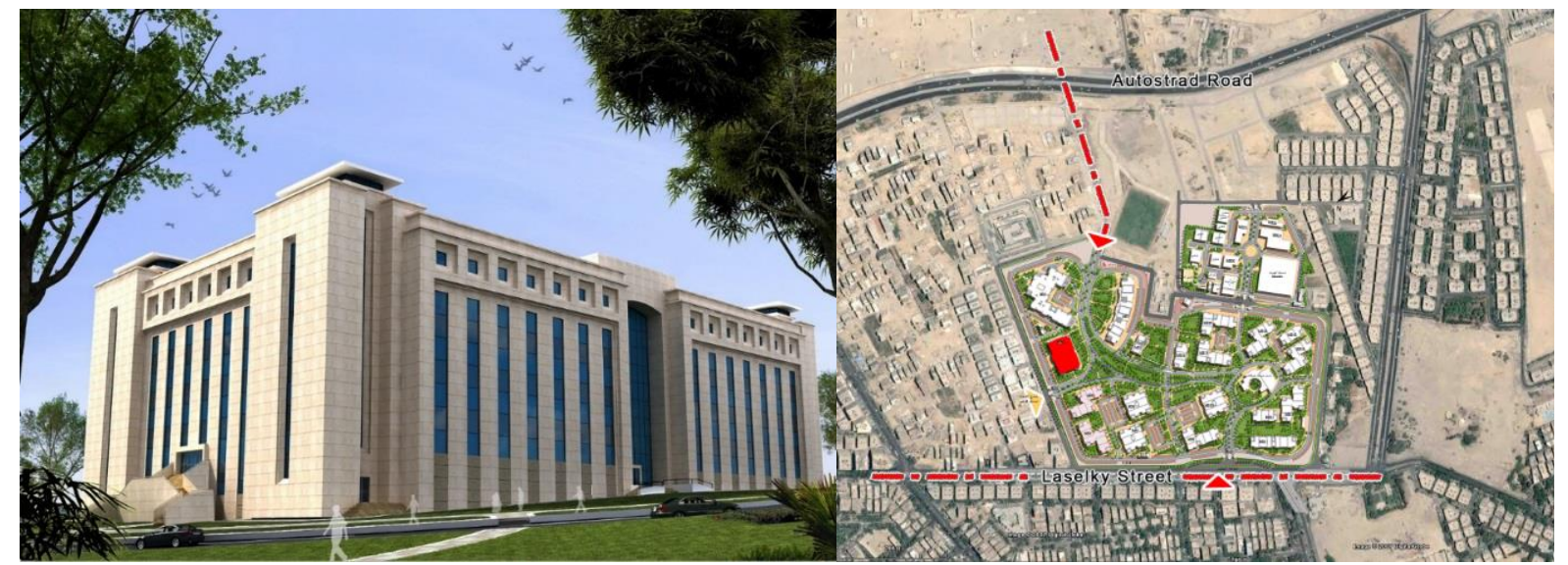

Figure 1: Building Overview \& Location

According to Figure 2, the basement floor is $4,000 \mathrm{~m}^{2}$ and sharing facilities to the entire building comprising main entrance, lounges, staircases, toilets and showers, electric utilities, services rooms and an outdoor area reserved for secure bicycles storage racks. The ground floor is $4,000 \mathrm{~m}^{2}$ and consist of one main entrance and two secondary entrances, lounges, public utilities, four large call center open spaces, and services rooms. The typical floor area is $4,000 \mathrm{~m}^{2}$ and consist of public utilities, four large call center open spaces, services rooms. The roof floor area is $1,000 \mathrm{~m}^{2}$ and consist of elevators machine rooms and storages. The external roof areas are dedicated to host all air conditioning equipment and solar panels collectors. 


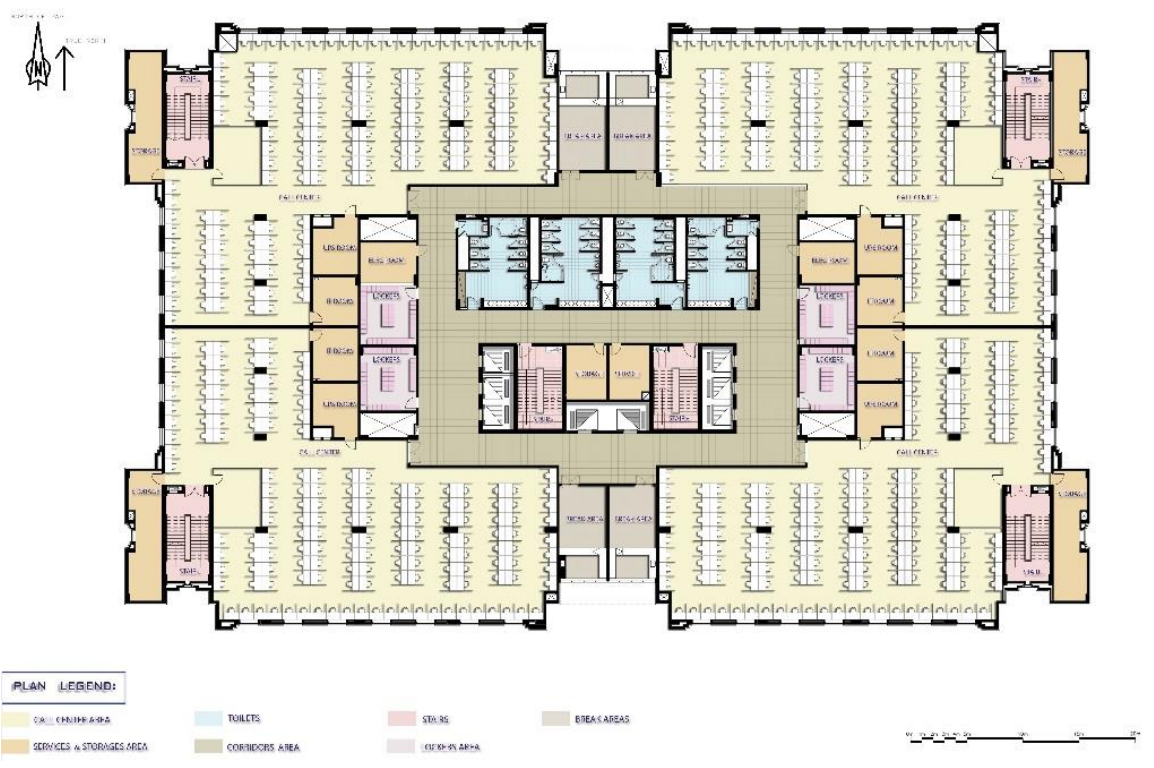

Figure 2: Building Typical Floor Plan

\section{Building Energy Modelling}

The selected platform for simulation is OpenStudio V.2.3, Sketchup V.17.0 and EnergyPlus V.8.8. This is an integrated open source platform which could predict building performance efficiently [23,24]. The modelling \& simulations processes done on DELL laptop with Intel® ${ }^{\circledR}$ Core $^{\mathrm{TM}} \mathrm{I5}-2430 \mathrm{M}$ CPU @ $2.40 \mathrm{GHz}$ processor, 12.0 GB RAM and NIVIDIA GeForce GT 525M by using Windows 7 Professional Service Pack 1.

The first step of work is to model the building by modelling the spaces including windows, doors or shading, see Figure 3. To Enter the weather information such as latitude, longitude, elevation and hourly weather data such as dry bulb temperature, dew point temperature, relative humidity, ..., etc., as mentioned in appendix 01 . The design year and weather file for Cairo, Egypt is used and obtained from (https://energyplus.net/weather-

\section{location/africa_wmo_region_1/EGY//EGY_Cairo.623660_IWEC).}

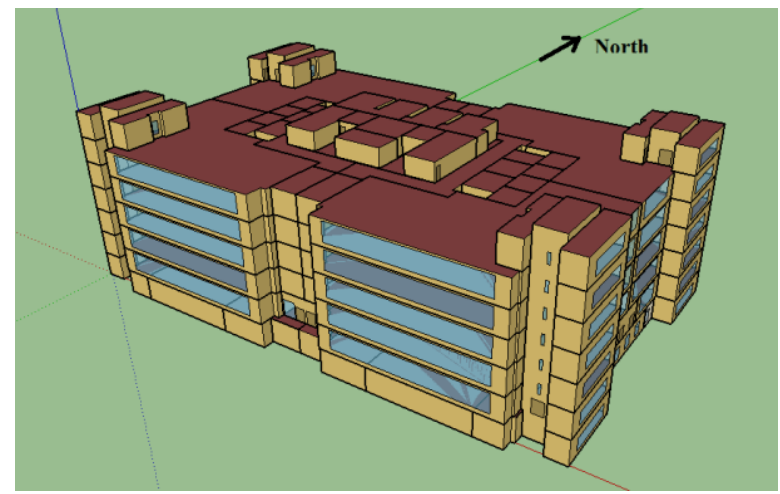

Figure 3: Building Model 


\subsection{Building Construction Modelling}

The building construction consists of interior walls, floors, fenestration, insulated exterior walls and roofs. The thermal resistance for each layer from the exterior walls could be found in [25] or from suppliers catalogues. The Fenestration of the building has solar heat gain coefficient (SHGC) which was 0.3 and heat transmission coefficient (U-Value) which was $1.44 \mathrm{~W} / \mathrm{m}^{2}$. K. The window to wall ratio according to [26] shall not exceed $40 \%$, in our building it is approximately $25 \%$.

\subsection{Building spaces modelling}

The building consists of 251 spaces could be classified to certain types based on the activity usage [27]. The building is operated for 24 hours on three consecutive 8 hrs. shift works. The building users in one shift is 3,093 persons with No transients, visitors or residents in the building. Each of space type have occupancy schedule according to building operation working shifts from $8 \mathrm{am}$ to $4 \mathrm{pm}$, from $4 \mathrm{pm}$ to $12 \mathrm{am}$ and from 12am to $8 \mathrm{am}$. These schedules are changing to be half in the week ends and official vacations as mentioned in Figure 5. Regarding to Ramadan month, the occupancy schedule was not affected in this period.

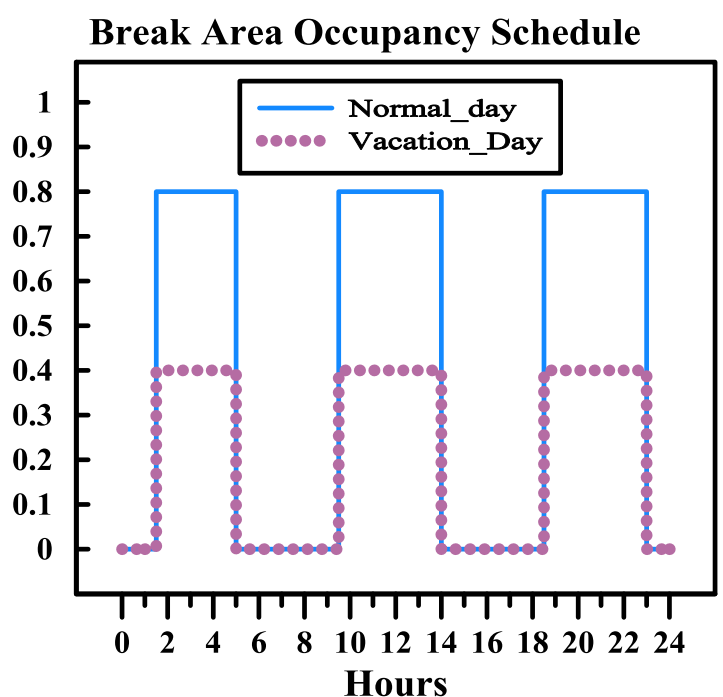

Hours

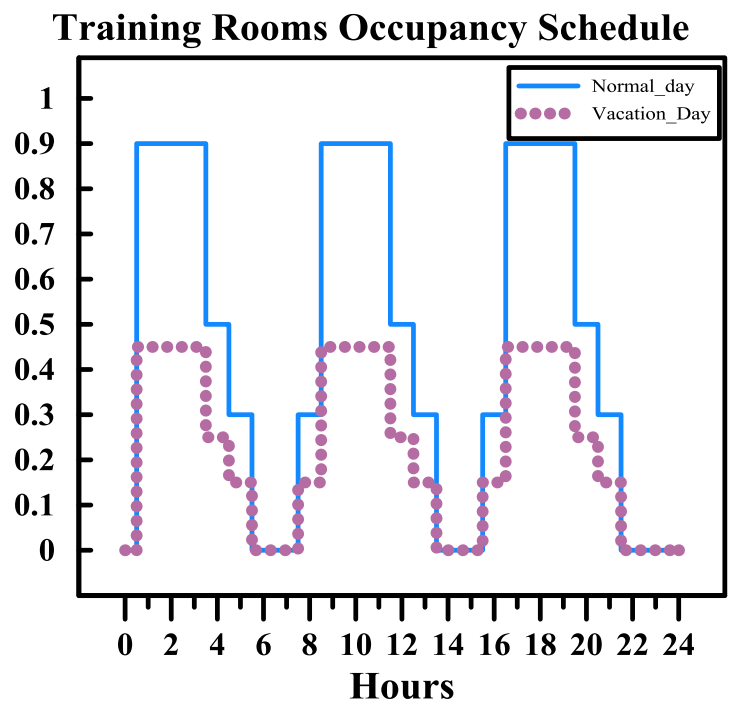


Call Center Occupancy Schedule

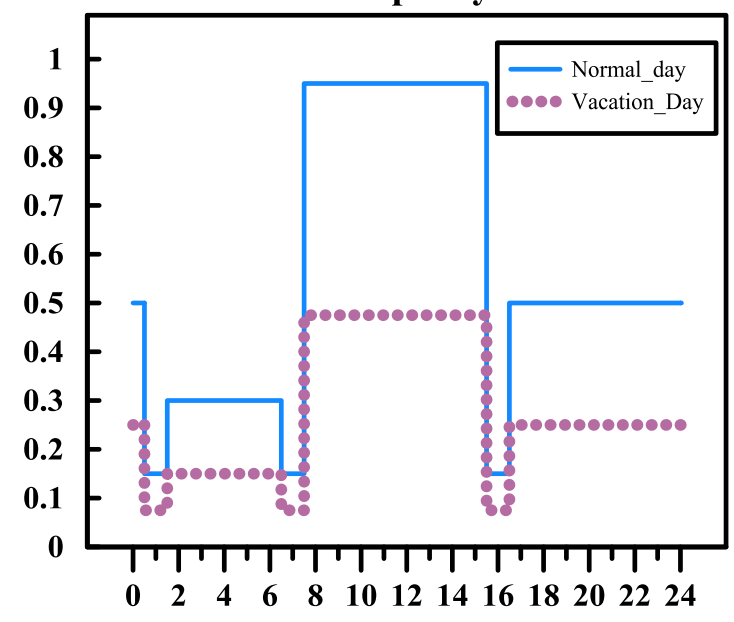

Hours

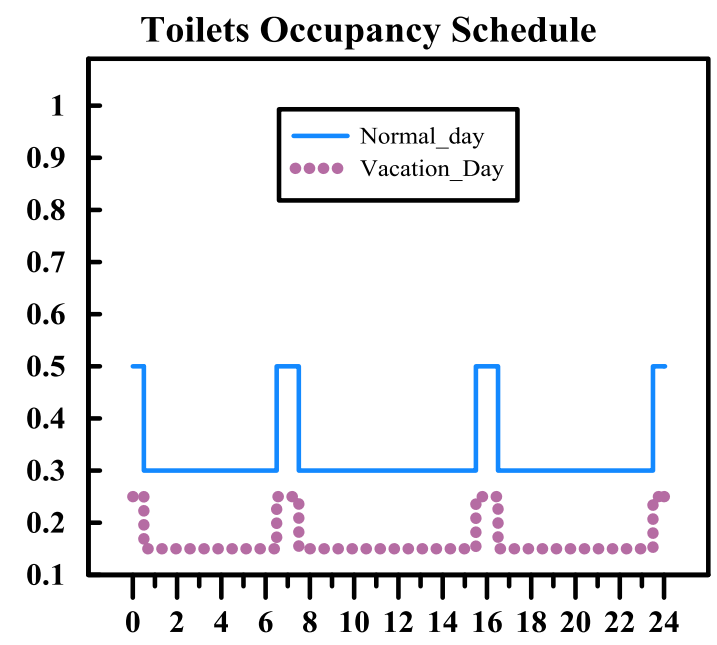

Hours

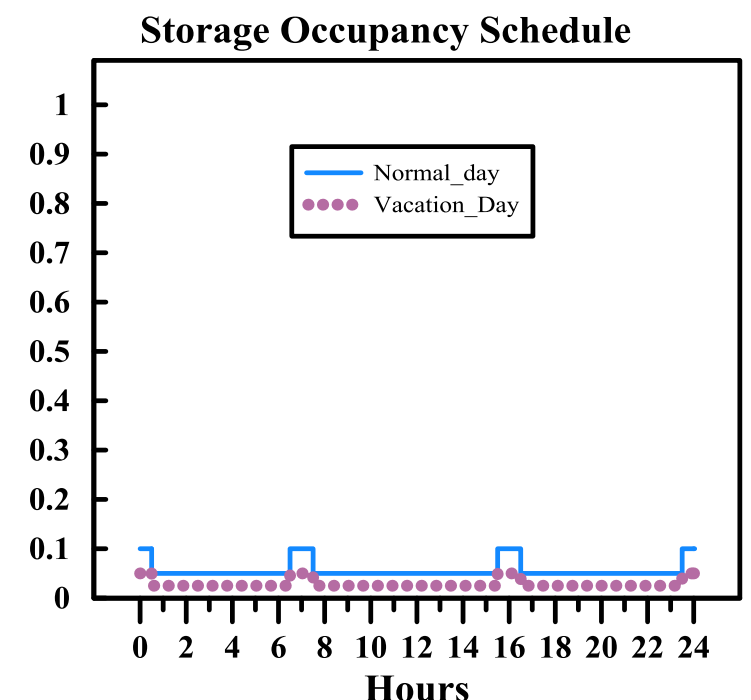

Hours

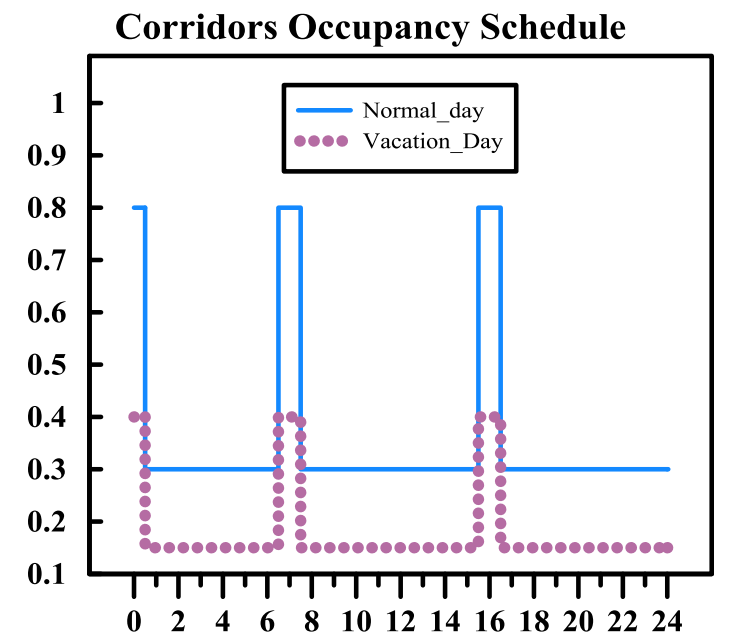

Hours

Figure 4: Occupancies Schedules
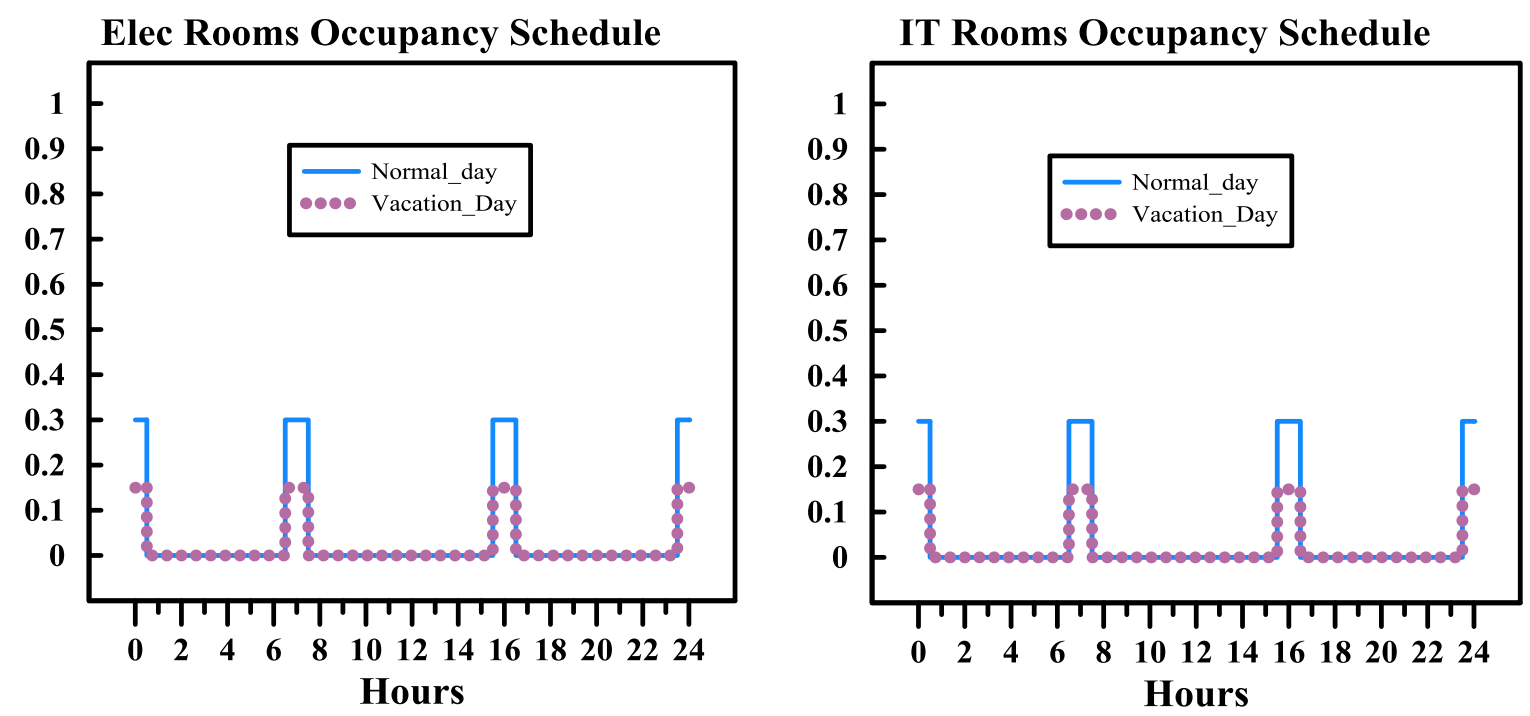
Lockers Occupancy Schedule

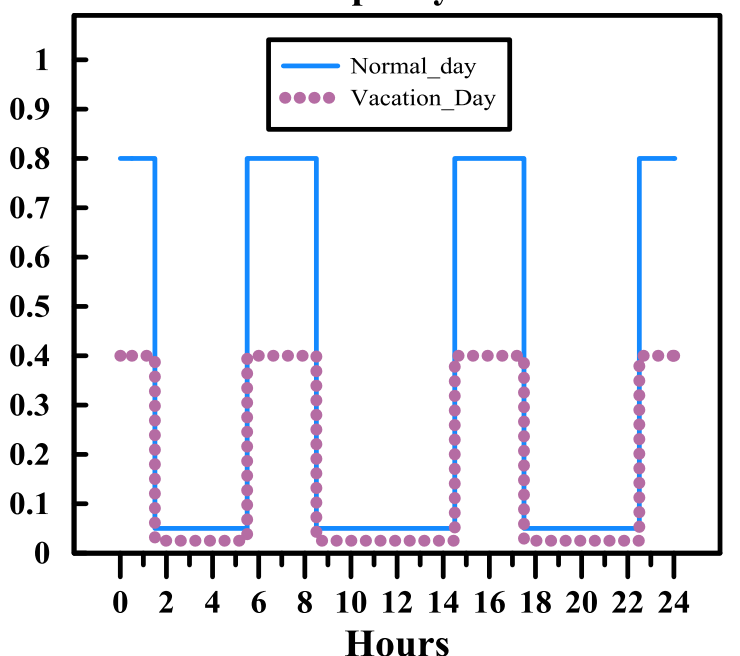

Stairs Occupancy Schedule

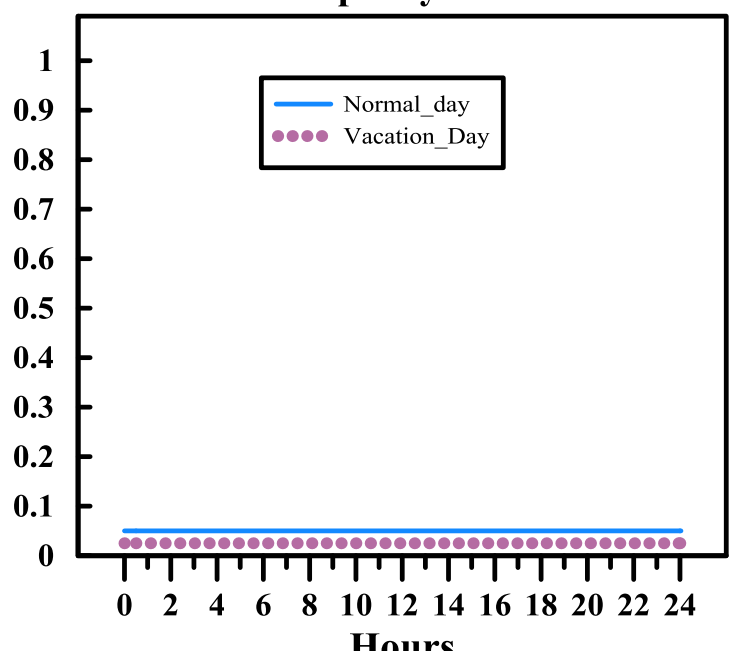

Figure 5: Occupancies Schedules (Continued)

\subsection{Building Spaces Internal Loads}

The spaces internal loads include electric plugs, equipment, lighting, people definitions and heat loads. First internal load is "people definition" which will be $8.22 \mathrm{~m}^{2} /$ person. The lighting power densities for the spaces and the equipment used in the building is according to [26] or depends on actual design.

Table 1 Spaces Lighting Power Densities (from the design package of the studied administration building)

\begin{tabular}{|l|l|l|l|}
\hline Space Type & $\begin{array}{l}\text { Lighting Power } \\
\text { Density }\left(\mathrm{W} / \mathrm{m}^{2}\right)\end{array}$ & Space Type & $\begin{array}{l}\text { Lighting Power } \\
\text { Density }\left(\mathrm{W} / \mathrm{m}^{2}\right)\end{array}$ \\
\hline Break Areas & 06.69 & Stairs & 06.00 \\
\hline Call Centers & 12.00 & Storages & 09.00 \\
\hline Corridors & 05.00 & Training Rooms & 12.78 \\
\hline IT \& Server Rooms & 13.83 & & \\
\hline
\end{tabular}

\subsection{Ventilation Loads}

Ventilation system uses powered fresh air handling units to provide fresh air to spaces as per [28]. The minimum ventilation rate to change indoor air according to occupancy category was per Table 2.

Table 2 Minimum Ventilation Rate [28]

\begin{tabular}{|l|l|}
\hline Space Type & Minimum Ventilation Rate $\left(\mathrm{m}^{3} / \mathrm{s}\right)$ \\
\hline Break Areas & $0.0025 /$ Person \\
& $0.0003 / \mathrm{m}^{2}$ \\
\hline Call Centers & $0.0025 /$ Person \\
& $0.0003 / \mathrm{m}^{2}$ \\
\hline Corridors & $0.0003 / \mathrm{m}^{2}$ \\
\hline IT \& Server Rooms & $0.0003 / \mathrm{m}^{2}$ \\
\hline
\end{tabular}




\begin{tabular}{|l|l|}
\hline Stairs & $0.0003 / \mathrm{m}^{2}$ \\
\hline Toilets & $0.315 /$ unit \\
\hline Lockers & $0.0025 / \mathrm{m}^{2}$ \\
\hline Storages & $0.0006 / \mathrm{m}^{2}$ \\
\hline Training Rooms & $0.0025 /$ Person \\
& $0.0003 / \mathrm{m}^{2}$ \\
\hline
\end{tabular}

\subsection{Air conditioning System}

The total conditioned areas are $19,342 \mathrm{~m}^{2}$ which consider $77.4 \%$ of the total building areas. Where's the unconditioned areas are $5,658 \mathrm{~m}^{2}, 22.6 \%$ of the total building areas. In the design stage the estimated cooling load for the building is 1050 T.R. The designer chooses a VRF system to apply for the building. Because of VRF system is sustainable, cost effective, lower maintenance costs and quiet operation. As important, VRF technology offers the ability to capture a significant number of points toward LEED certification. The VRF system in the building uses R410a refrigerant with 3.3 rated cooling COP and 3.5 rated heating COP.

\section{Base case results}

The base model is the building model without air conditioning system, retrofitting technologies or any renewable energy source. The base case result can be obtained from Figure 6. These loads were ideal loads (cooling or heating) without applying any air conditioning systems.

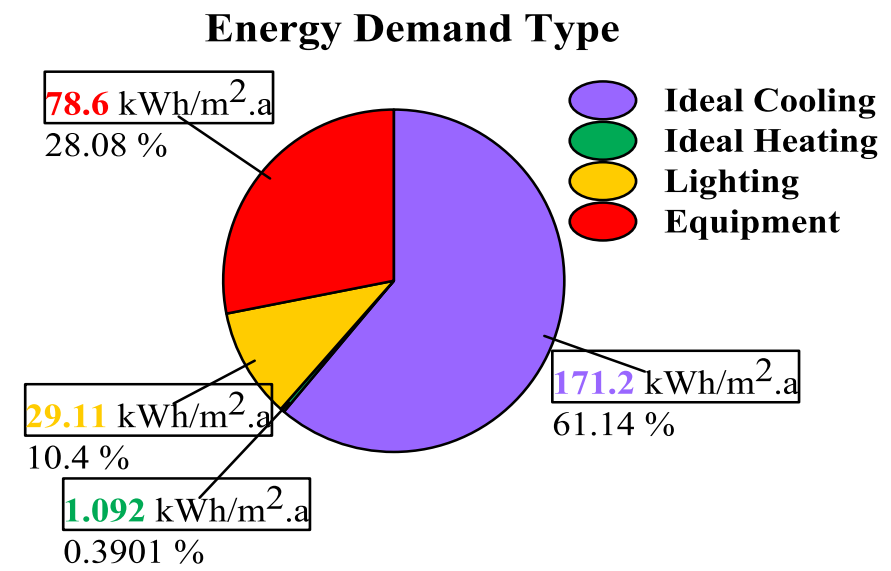

(a) Annually

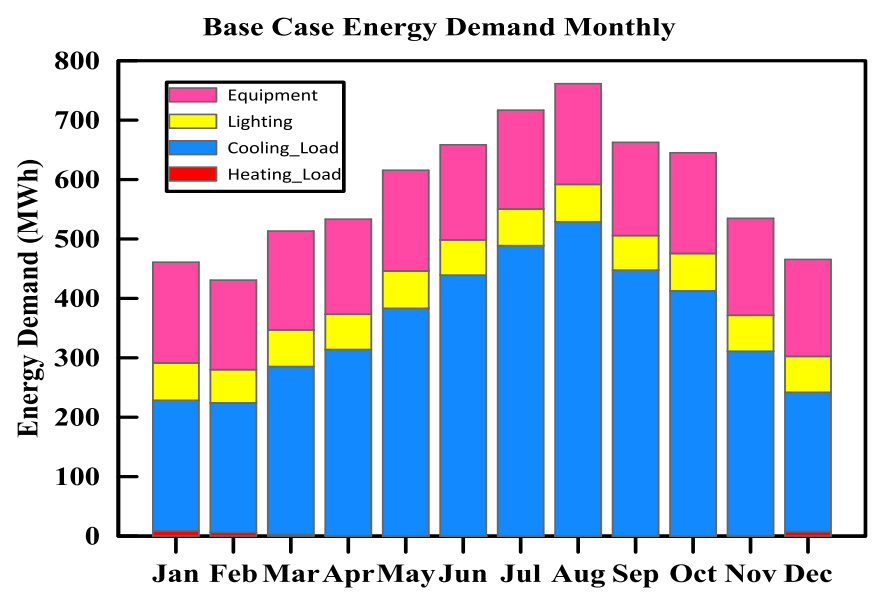

(b) Monthly

Figure 6: Base Case Demand Energy

\section{Building Model Validation}

The next step is applying all the site specifications, properties and air conditioning system from real building to the simulated model. We found that the simulated building consumes $5,010,426.7 \mathrm{kWh} / \mathrm{a}\left(200.417 \mathrm{kWh} / \mathrm{m}^{2}\right.$. a). 
By comparing the simulated model with the actual building, we found that the real building consumes 4,965,201 $\mathrm{kWh} / \mathrm{a}\left(198.6 \mathrm{kWh} / \mathrm{m}^{2}\right.$. a) according to building meters readings in 2017. The max. deviation value between the simulated model and the actual building is $8 \%$ and not more than $0.9 \%$ as an average along the year. The deviation is because of the inaccuracy of weather file, the human error in reading meters and because the actual occupancy has non-measured changes and the obtained data were on a monthly scale. The monthly energy demand deviation as shown in Figure 7. This is reliable and suitable to applying the retrofitting technologies.

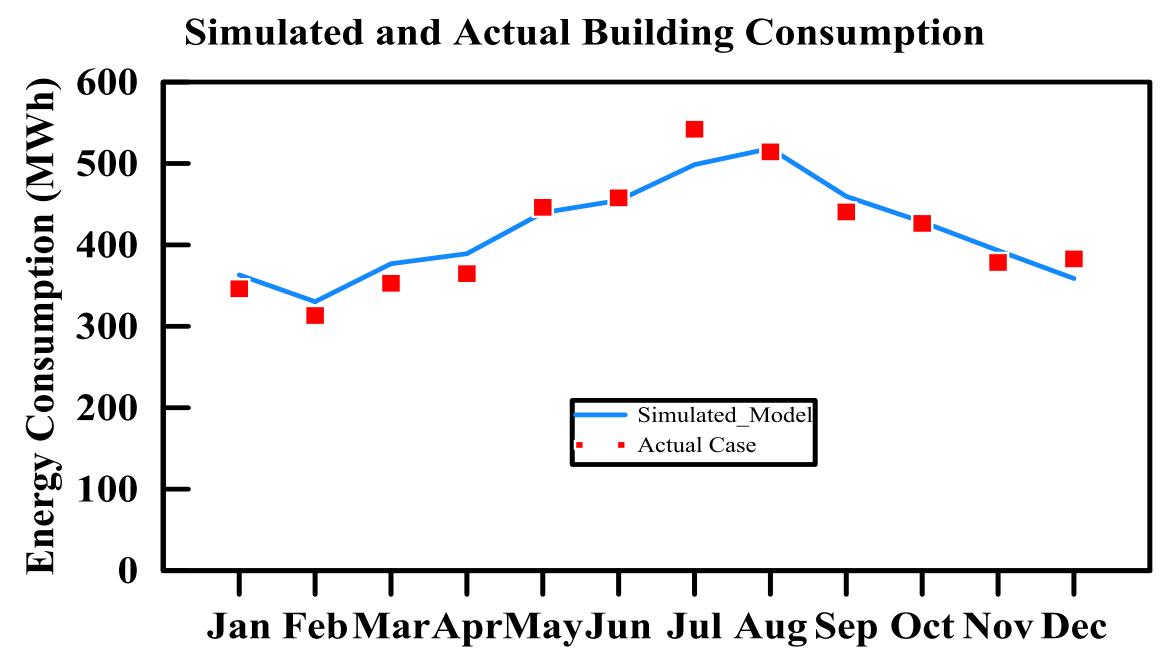

Figure 7: Monthly Energy Demand Deviation

\section{The Model Modifications}

The energy efficiency measures (EEM) are divided to passive and active. The passive EEM. consist of the measures in the architecture model to reduce the energy consumption while maintaining the comfort conditions. These include changing the orientation of the building, adding external wall insulation, internal wall insulations, shading on the windows and changing the window types.

The active energy saving technologies is more applicable where the building is already existed. The most common active technologies are decrease the energy consumption in lighting systems by using energy saving lighting fixtures (Fluorescent, LED lamps, etc.) instead of high wattage lamps. The effect of implementing these measures on the base model were studied and compared with the reference model.

\subsection{Effect of The Orientation}

In the base model we could found that the orientation of the building and the north direction is according to the architecture design as per Figure 2. According to the nature of the building and its similarity, the recommendations is studying the 
building rotations by $30,45,60,90$ degrees (C.C.W.) only. That is appropriate to describe all the available orientations. The orientation changes affect only on the cooling and heating loads. So, the comparison will be between them only.

Figure 8 shows that we can achieve a lower cooling load by directing the building to be the longest side in the north direction and this is comply with [29]. We can achieve a highest heating load by directing the building to be $90^{\circ}$ rotation from the north direction. The base model case is the lowest energy consumption (279.955 $\mathrm{kWh} / \mathrm{m}^{2}$. a). The $90^{\circ}$ building rotation is the highest energy consumption $(282.308$ $\mathrm{kWh} / \mathrm{m}^{2}$. a). There is no energy reduction done by rotating the building 30, 45, 60 or $90^{\circ}$.

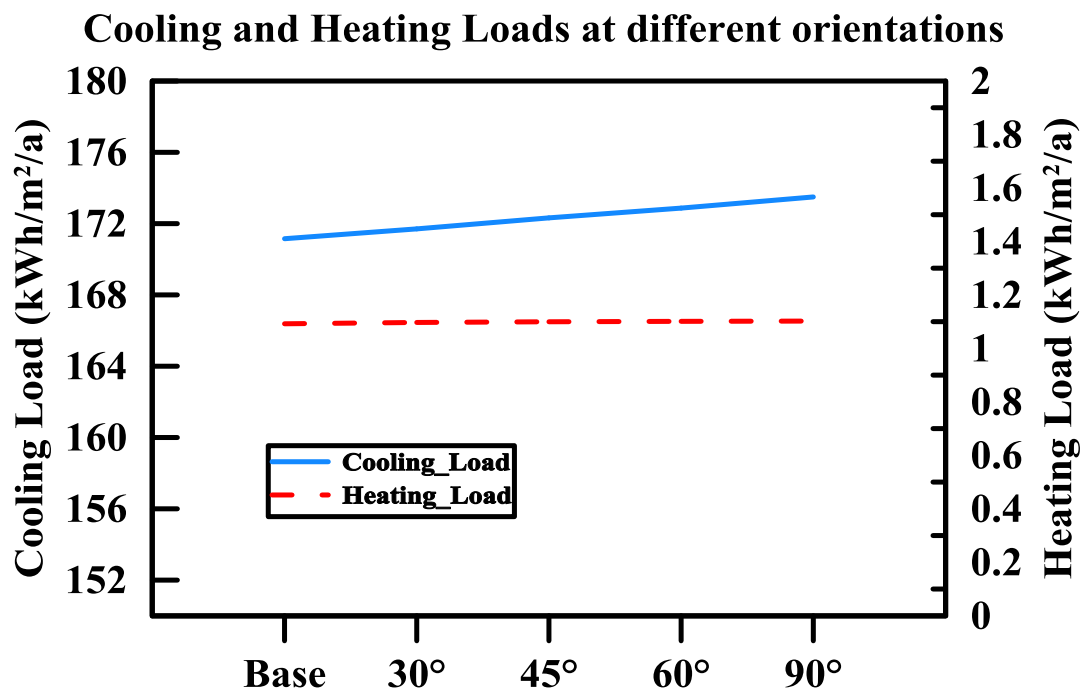

Figure 8: Cooling and heating loads at different orientations

\subsection{Effect of The Wall Insulation}

According to building design, we could find that the exterior wall insulation consists of $50 \mathrm{~mm}$ thermal rigid insulation board, $25 \mathrm{~mm}$ air gap and $50 \mathrm{~mm}$ mechanical fixed Hashma stone cladding. So, there is no obvious effectiveness for changing the exterior insulations or adding any modifications. The other direction is to add interior wall insulations. It has different types. In this case we will use the polystyrene board insulation. The base model has $\left(0.28 \mathrm{~W} / \mathrm{m}^{2} . \mathrm{K}\right) \mathrm{U}$-value and with the insulation the U-values changed from 0.2 to $0.18 \mathrm{~W} / \mathrm{m}^{2}$. $\mathrm{K}$ with 0.01 step. Smooth boards have $0.035 \mathrm{~W} / \mathrm{m}$. K conductivity, $22 \mathrm{~kg} / \mathrm{m}^{3}$ density and $840 \mathrm{~J} / \mathrm{kg}$. K specific heat.

By adding internal insulation and increase the thickness, we could reach maximum reduction in cooling load. But as a comment the difference in cooling load between $0.28 \mathrm{~W} / \mathrm{m}^{2}$. K U-value and $0.18 \mathrm{~W} / \mathrm{m}^{2}$. K U-value is slight. It will cost higher than its value. On the other hand, we can achieve a lowest heating load by applying 0.18 $\mathrm{W} / \mathrm{m}^{2}$. K U-value. So, the energy consumption was reduced by decreasing the Uvalue but the reduction is small. These results are complying with the nature of the 
building. That the administration buildings which have good insulated facades, the major loads will be from the internal loads not from external.

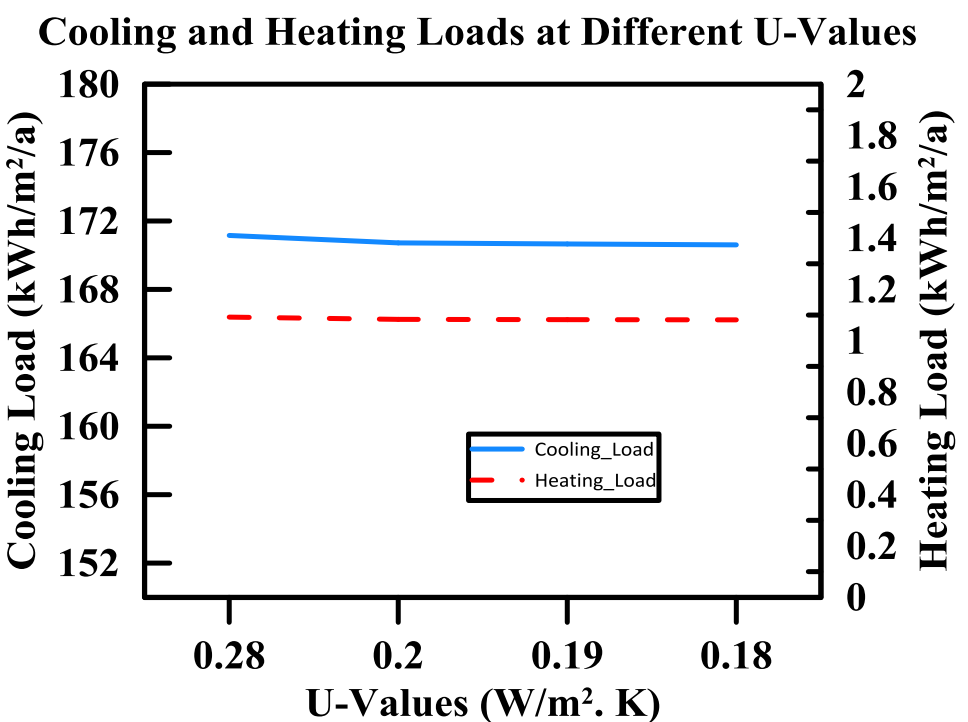

Figure 9: Cooling \& Heating Loads at different U-Values

\subsection{The Glazing Type}

The glazing type already exist in the building is double glazing with air space. Which have $1.44 \mathrm{U}$-value, good Reflectiveness with moderate transmittance and moderate solar heat gain. So, in this case the existing glazing type is an effective type for energy conservation. We will study other types of window glazing and its effects on the energy consumption. According to Figure 10, the lowest cooling load will be achieved while using glazing type 07. The single window glazing types will not affect the energy consumption the satisfactory effect. The highest cooling loads occurs when using glazing type 01 . On the other hand, the lowest heating load is regarding type 01 . The highest heating load occurs at using glazing type 04.

Table 3 Different Glazing types [26]

\begin{tabular}{|l|l|l|l|l|l|}
\hline Types & Name U & SC & SHGC & Tvis \\
\hline 00 & Base Model & 1.44 & N/A & 0.3 & N/A \\
\hline 01 & Single Glazing (Blue) & 6.17 & 0.71 & 0.61 & 0.57 \\
\hline 02 & Single Glazing (Grey) & 6.17 & 0.69 & 0.59 & 0.43 \\
\hline 03 & $\begin{array}{l}\text { Single Reflective (Class A) 1 Clear } \\
\text { High Emissivity }\end{array}$ & 5.41 & 0.36 & 0.31 & 0.2 \\
\hline 04 & $\begin{array}{l}\text { Single Reflective (A) Tint Medium } \\
\text { Emissivity }\end{array}$ & 5.11 & 0.29 & 0.25 & 0.09 \\
\hline 05 & $\begin{array}{l}\text { Double Glazing Tint Low Emissivity } \\
\text { Double Glazing, Reflective (A) Clear } \\
\text { Medium Emissivity (IG)2 }\end{array}$ & 1.78 & 0.37 & 0.28 & 0.44 \\
\hline 07 & $\begin{array}{l}\text { Double Glazing, Reflective (A)Tint, } \\
\text { Medium Emissivity (IG) }\end{array}$ & 2.35 & 0.18 & 0.15 & 0.08 \\
\hline
\end{tabular}


Where:

$\mathrm{U}$ :

SC:

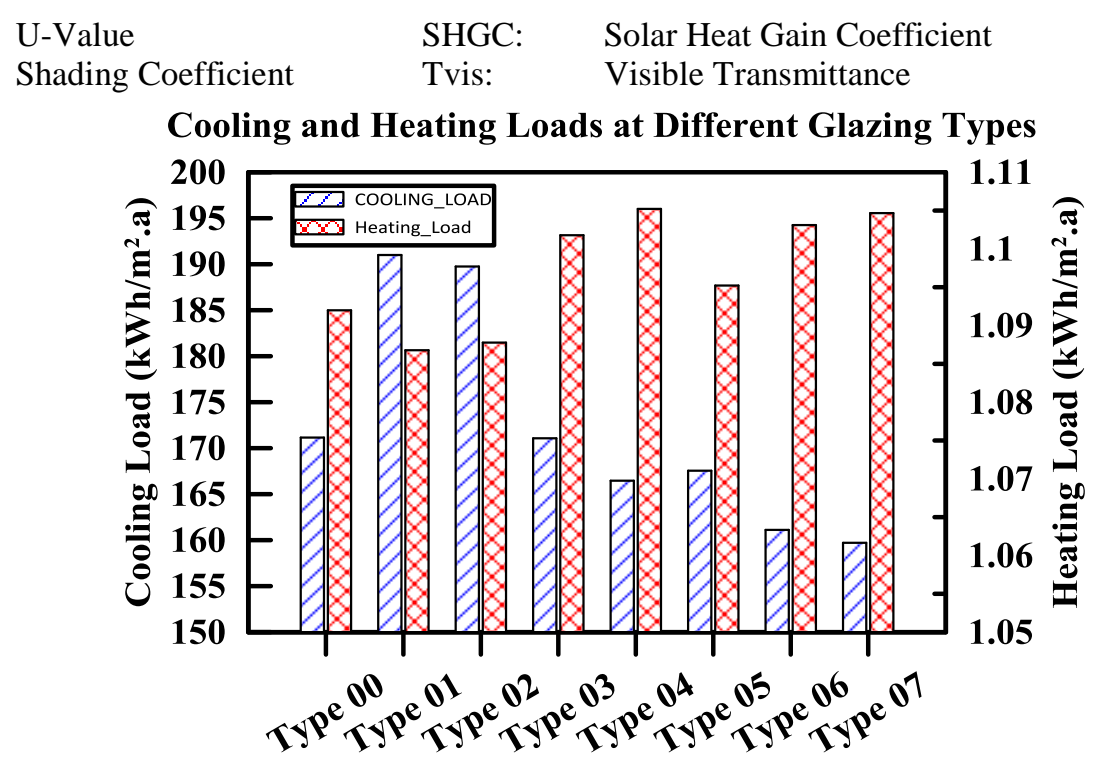

Figure 10: Cooling and heating loads at different Glazing Types

\subsection{Effect of The Shading}

The most popular passive method to control the sunlight and undesirable solar heat is the façade window shading. These unwanted rays can cause occupant discomfort and increase the air conditioning loads. The projection factor is the way to characterize the horizontal shading impact on the façade windows. The projection factor is the ratio between the horizontal shading length and the window height. In the base model the façade windows are exposed to sunlight. The external shading is just the area plants and it is not effective which could be neglectable. So, the modification in this study will be in the projection factor only fixing the shading angle by $15^{\circ}$.

The projection factors were changed $0.4,0.6,0.8$ to 1.0 . and were studied in all directions separately and together. At north direction, as per Figure 11, we could find that when increasing the projection factor to 1.0, the cooling load decreases by $0.32 \%$ and the heating load increases by $0.03 \%$. The reduction ratio from 0.10 to $0.19 \%$ and not up to $1 \%$ at least.

When increasing the projection factor to 1.0 at east direction, the cooling load decreases by $0.78 \%$, and the heating load increases by $0.07 \%$. The reduction ratio changes from 0.26 to $0.48 \%$ and not up to $1 \%$ at least. At south direction, we could find that the cooling load decreases by $3.46 \%$ and the heating load increases by $0.69 \%$. The reduction ratio changes from 1.15 to $2.11 \%$ and that is more efficient than the other directions. Because the biggest side of the building is in south direction and according to [29] that it has the biggest percentage in loads. At west direction, the cooling load decreases by $0.73 \%$ and the heating load increases by $0.05 \%$. The reduction ratio changes from 0.22 to $0.44 \%$ and not up to $1 \%$ at least. At all direction, the cooling load decreases by $5.29 \%$ and the heating load increases 
by $0.77 \%$. The reduction ratio changes from 1.75 to $3.23 \%$ and that is more efficient than the other directions.

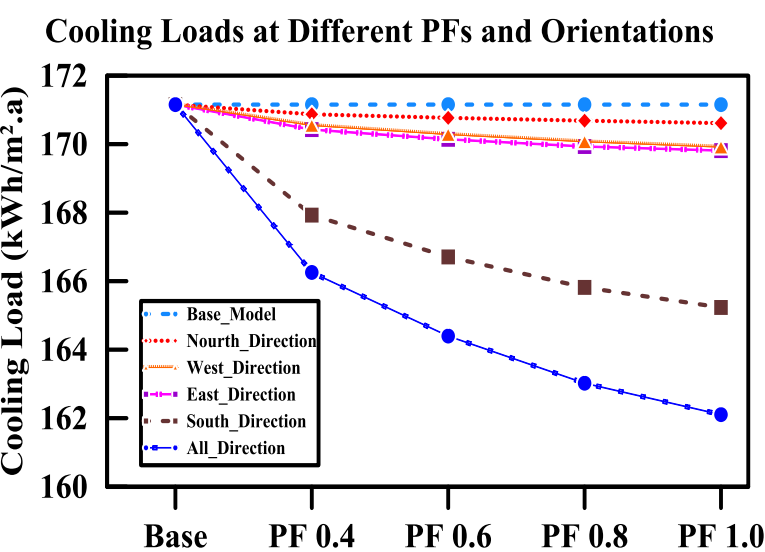

(a) Cooling Load

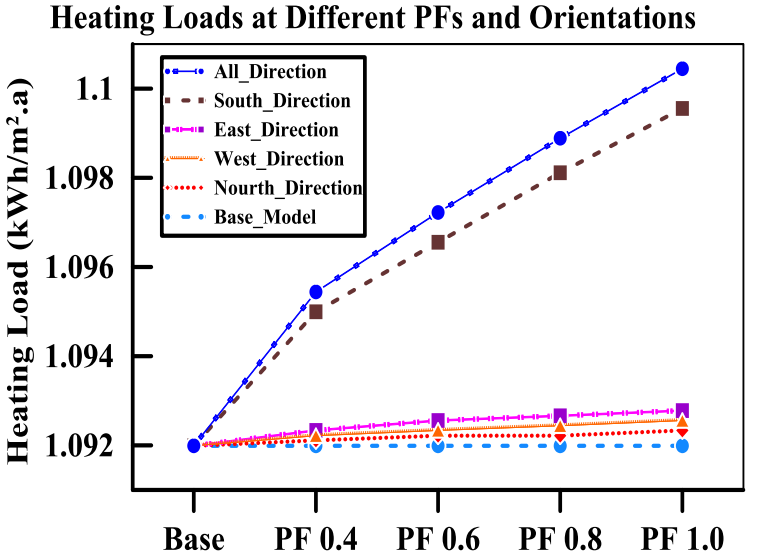

(b) Heating Load

Figure 11: Cooling and heating Loads at Different PFs \& Orientations

\subsection{Effect of The Lighting fixtures modification}

Lighting in the office building is important to achieve the visual comfort requirement. It affects the capability of employees to accomplish the tasks efficiently. The low or high light levels may cause eye strain and fatigue. The building lighting system design is according to [30]. Taking into consideration the lux requirements according to the area application. In the actual case the lighting fixtures used is a florescent lighting. Each lamp produces $840 \mathrm{~lm}$ and consumes 14 watts. It has high lighting efficiency which is equal to $60 \mathrm{~lm} / \mathrm{watt}$. According to the existing lighting system data, we could estimate the lux for spaces types by using Table 4 and according to table (2-26) in [30]. The study includes 4 types of lighting fixtures. Florescent lamps are the base model lighting fixtures and will compared to incandescent, CFL \& LED Lamps. With fixing the design lighting lux level.

Table 4 Base Model Lighting Intensity (from the design package of the studied administration building)

\begin{tabular}{|c|c|c|c|}
\hline Areas & $\begin{array}{l}\text { Base Model } \\
\text { lighting intensity } \\
\left(\text { Watt } / \mathrm{m}^{2}\right)\end{array}$ & Areas & $\begin{array}{l}\text { Base Model } \\
\text { lighting intensity } \\
\left(\text { Watt } / \mathrm{m}^{2}\right)\end{array}$ \\
\hline Break Area & 6.69 & Stairs & 6 \\
\hline Call Center Room & 12 & Storages & 9 \\
\hline Corridors & 5 & Training Rooms & 12.78 \\
\hline IT \& Server Rooms & 13.83 & & \\
\hline
\end{tabular}

The lighting types incandescent \& CFL was taken from [30]. Incandescent lighting efficacy taken is equal to $17.4 \mathrm{~lm} /$ Watt and the CFL is equal to $78.9 \mathrm{~lm} / \mathrm{Watt}$. The base model florescent lamps lighting efficacy is according to supplier catalogue which is equal to $60 \mathrm{~lm} / \mathrm{Watt}$. The LED lamps lighting efficacy is according to the 
same lux for the florescent base model and from the same supplier is equal to $106.67 \mathrm{~lm} /$ Watt. So, we could estimate the different lighting intensity by knowing the lux per $\mathrm{m}^{2}$ in different spaces. The lighting intensity for different lighting fixtures will be shown in Table 5.

Table 5 Different lighting intensity

\begin{tabular}{|l|l|l|l|l|}
\hline & $\begin{array}{l}\text { Incandescent } \\
{\left[\mathrm{Watt} / \mathrm{m}^{2}\right]}\end{array}$ & $\begin{array}{l}\mathrm{FLO} \\
{\left[\mathrm{Watt} / \mathrm{m}^{2}\right]}\end{array}$ & $\begin{array}{l}\mathrm{CFL} \\
{\left[\mathrm{Watt} / \mathrm{m}^{2}\right]}\end{array}$ & $\begin{array}{l}\mathrm{LED} \\
{\left[\mathrm{Watt} / \mathrm{m}^{2}\right]}\end{array}$ \\
\hline Break Area & 23.07 & 6.69 & 5.09 & 3.76 \\
\hline Call Center Room & 41.38 & 12 & 9.13 & 6.75 \\
\hline Corridors & 17.24 & 5 & 3.8 & 2.81 \\
\hline IT \& Server Room & 47.69 & 13.83 & 10.52 & 7.78 \\
\hline Stairs & 20.69 & 6 & 4.56 & 3.37 \\
\hline Storages & 31.03 & 9 & 6.84 & 5.06 \\
\hline Training Rooms & 44.07 & 12.78 & 9.72 & 7.19 \\
\hline
\end{tabular}

According to Figure 12, the lowest cooling load was achieved while using LED lighting fixtures. The highest cooling loads was achieved when using Incandescent Lighting fixtures. On the other hand, the lowest heating load was achieved while using Incandescent lighting fixtures. The highest heating loads was achieved when using LED Lighting fixtures. The change in lighting type decrease the cooling load with $7.9 \%$ from the base case and increase the heating loads with $5.5 \%$ but its major effect is in the lighting load which decreases by $43.8 \%$. The total saving in energy is 9.4\%. Implementing LED lighting causes the lowest energy consumption. Implementing the incandescent causes the highest energy consumption.

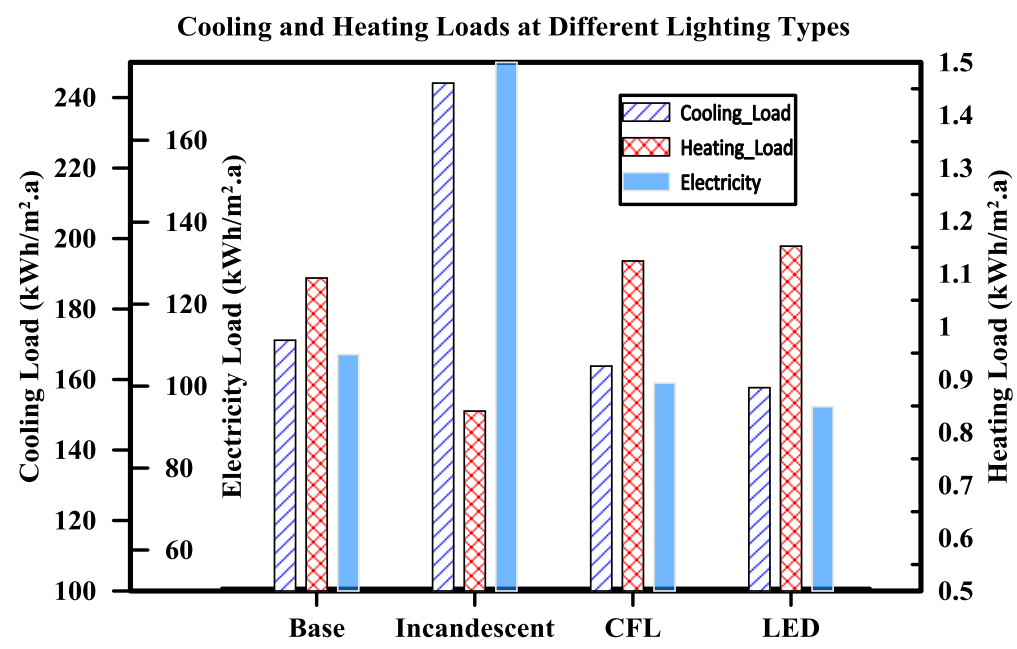

Figure 12: Cooling and heating loads at different Lighting Intensity

\section{The Optimization}

The optimized model properties to achieve the lowest energy consumption: 
1- The orientation is 0 degree from the base case model. The longest glazing side will be in north direction

2- There is no any internal wall insulation. The energy reduction in existence of exterior insulation (Hashma Stone) is not effective.

3- The glazing type is Type 07 Glazing (Double Glazing, Reflective (A) Tint, Medium Emissivity (IG)).

4- The lighting type is LED lighting.

5- The shading is in south direction only and the projection factor will be 1.0 .

After applying these measures on the validated base model, we found the result in Table 6. The conclusion was that the total cooling load reduced by $13.1 \%$. When the total heating load increased by $44.6 \%$. The internal lighting load decreased by $43.76 \%$ where the equipment load decreased by $2.17 \%$. As a result of these modifications, the total reduction in energy is $11.925 \%$ before applying any renewable energy production source.

Table 6 Optimized System Model Comparing to Validated Model

\begin{tabular}{|l|l|l|l|}
\hline Load Type & $\begin{array}{l}\text { Validated Model } \\
{\left[\mathrm{kWh} / \mathrm{m}^{2} . \mathrm{a}\right]}\end{array}$ & $\begin{array}{l}\text { Optimized System Model } \\
{\left[\mathrm{kWh} / \mathrm{m}^{2} . \mathrm{a}\right]}\end{array}$ & $\begin{array}{l}\text { Reduction } \\
\text { Percentage \% }\end{array}$ \\
\hline Heating Load & 0.943 & 1.364 & $-44.58 \%$ \\
\hline Cooling Load & 72.157 & 62.708 & $13.095 \%$ \\
\hline Lighting Load & 29.111 & 16.373 & $43.76 \%$ \\
\hline $\begin{array}{l}\text { Equipment } \\
\text { Load }\end{array}$ & 98.205 & 96.073 & $2.17 \%$ \\
\hline Total Load & 200.417 & 176.518 & $11.925 \%$ \\
\hline
\end{tabular}

\section{Adding Photovoltaic panels to the optimized model:}

The suitable method for energy production in this case is the solar photovoltaic panels to produce electricity direct to be utilized first to cover part of on-site electricity loads and export the surplus (if any) to the grid. After contracting with the local electric production company and by using bidirectional meter. The photovoltaic panels are proposed to be oriented horizontally. That could achieve a suitable power generation with avoidance the shadow effect and simplification the simulation procedures. The photovoltaic panels efficiency assumed to be $18 \%$ according to the commonly used in the local market. The active area was $90 \%$ from surface area and the inverter efficiency would assume to be $95 \%$. The suggested locations for these photovoltaic panels are the roof and the parking area outside the building. The useful area for support the photovoltaic panel is $3,508 \mathrm{~m}^{2}$ and the parking area is $2,107 \mathrm{~m}^{2}$. The total available area for photovoltaic panels is 5,616 $\mathrm{m}^{2}$, which produces $1,296,191 \mathrm{kWh} / \mathrm{a}\left(230.82 \mathrm{kWh} / \mathrm{m}^{2}\right.$. a. for the panels area).

The optimized building net site energy before adding the photovoltaic panels was $4,409,714 \mathrm{kWh} / \mathrm{a}\left(176.39 \mathrm{kWh} / \mathrm{m}^{2}\right.$. a). After applying the photovoltaic panels, it 
reduced to $3,113,523 \mathrm{kWh} / \mathrm{a}\left(124.54 \mathrm{kWh} / \mathrm{m}^{2}\right.$. a) with $29.45 \%$ reduction percentage. The reduction in energy consumption for the building after applying all the proposed modifications is $37.86 \%$ in comparing with the actual building electricity bill. We could find that percentage in energy conservation is very sufficient to be implemented. The monthly comparison will be according to Figure 13.

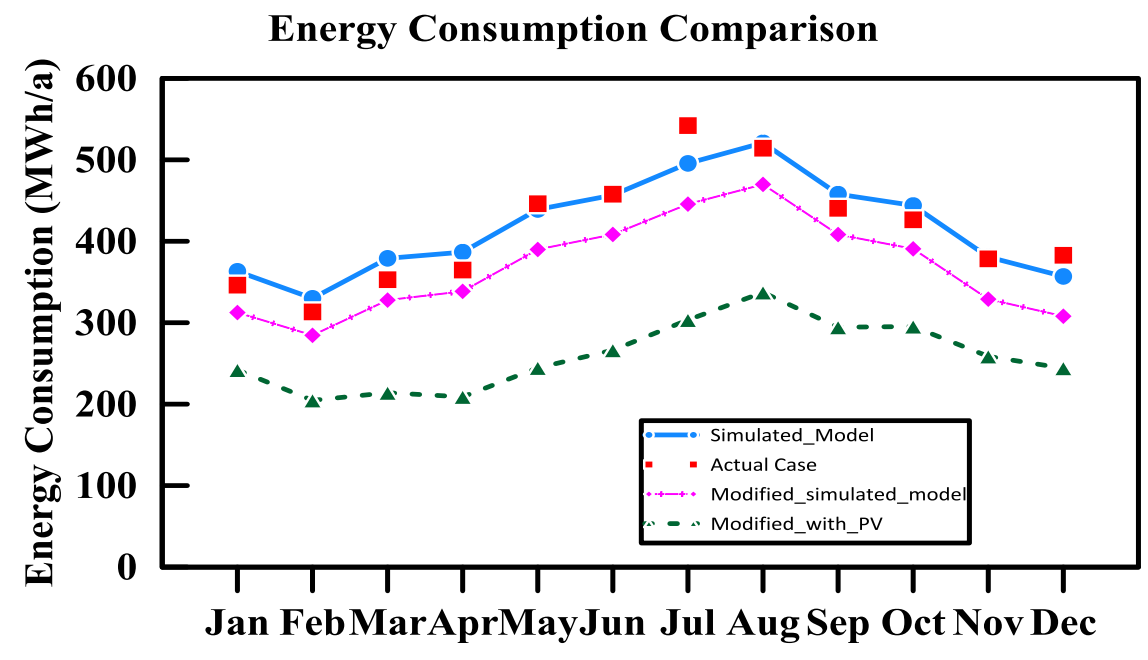

Figure 13: Monthly Energy Consumption comparison

\section{Achieving Net Zero Energy Building}

The photovoltaic panels area required to achieve NZEB will be calculated. The existing area which could be used is $5,616 \mathrm{~m}^{2}$ which produce $1,296,191 \mathrm{kWh} / \mathrm{a}$. The building net energy consumption after cover these areas with photovoltaic panels will be $3,113,523 \mathrm{kWh} / \mathrm{a}$. The simulated photovoltaic panels produce 230.82 $\mathrm{kWh} / \mathrm{m}^{2}$ of the panels area. So, the area required to produce $3,113,523 \mathrm{kWh} / \mathrm{a}$ shall be more than $13,489 \mathrm{~m}^{2}$. It is approximately 3.37 times of building floor area.

\section{Life Cycle Cost Analysis}

In this section the life cycle cost (LCC) estimation will be discussed. The life cycle cost of the modifications will be the summation of all the modifications cost individually. The one modification cost will be including capital, replacement and maintenance costs in the present value. The life cycle period in this study is assumed to be 20 years according to [31].

The capital cost estimations were applied to all energy efficiency measures (Glazing, Shading, LED lighting and PV panels). The running and maintenance costs were estimated according to lifetime and maintenance schedule of each measure. The glazing and shading have a long lifetime which is approximately 20 years. So, there is no cost for change it along the lifecycle period. Its maintenance schedules are not available so, its maintenance was condition based or nonpredictive maintenance and couldn't be estimated. So, it could be neglected. The 
LED Lighting and PV panels are estimated along lifetime period of the measure according to the manufacturer recommendations.

Taking into considerations the changes between the future value and the present value of the implemented measures. The inflation rate in 2019 was $9.2 \%$ according to [32] and interest rate in the same year was $16.25 \%$ as mentioned in [33]. The present value is calculated to estimate the value of the future amount of money according to [31]

The first energy efficiency measure was the glazing type exchange to be Type 07 Glazing. The total glazing area form the simulated model was $2,487 \mathrm{~m}^{2}$ approximated to $2,500 \mathrm{~m}^{2}$. The cost of supply and install $1 \mathrm{~m}^{2}$ from this type of glazing in the local market was varies from 850 to 1,200 L.E including the cladding, frame $\&$ shading (according to contacted suppliers). By taking the average price to be 1,000 L.E. so, the cost of glazing \& shading changes is 2,500,000 L.E.

The second energy efficiency measure is the lighting fixture replacement with LED lighting fixtures. The building contains 3 major types of lighting fixtures as shown in Table 7. The price is according to the local market supplier (PHILIPS).

According to Table 7 the capital cost of changing the lighting fixture in the building cost $1,794,800$ L.E. The running or maintenance cost for lighting fixtures was according to lifetime period of lighting fixtures and during building lifetime period. The total working hours for the building was obtained from simulation results and the actual running schedule for the building. The working hours for lighting in the building were 8,279.2 hours. by year 2017. Along 20 years the $8 \mathrm{~W} 600 \mathrm{~mm}$ LED tube \& $14.5 \mathrm{~W} 1200 \mathrm{~mm}$ LED tube will be purchased 6 times the first one and after $3.62,7.25,10.87,14.5,18.12$ years. The 9W LED Bulb will be purchased also 17 times the first one and after 1.21 years periodically. So, The Lighting replacement cost is 6,908,289 L.E.

With considering the old lighting fixture maintenance cost. The existing lighting fixtures have life time $6,000,20,000 \& 20,000$ hours. With initial supplier price $114,100 \& 120$ L.E. So, there maintenance cost was estimated to be 6,398,365 L.E. According to these estimations, the net lighting cost is 509,924 L.E.

Table 7 Lighting Fixture replacement cost

\begin{tabular}{|c|c|c|c|c|c|}
\hline $\begin{array}{l}\text { No. of } \\
\text { Fixtures }\end{array}$ & $\begin{array}{l}\text { Existing } \\
\text { Lighting } \\
\text { Fixtures }\end{array}$ & $\begin{array}{l}\text { New } \\
\text { Lighting } \\
\text { Fixtures }\end{array}$ & $\begin{array}{l}\text { New } \\
\text { Fixtures } \\
\text { life time }\end{array}$ & $\begin{array}{l}\text { Total cost } \\
\text { (Supplying \& } \\
\text { Installation) }\end{array}$ & $\begin{array}{l}\text { The } \\
\text { replacement } \\
\text { Total cost }\end{array}$ \\
\hline 671 & $\begin{array}{l}18 \mathrm{~W} \\
\text { Compact }\end{array}$ & $\begin{array}{l}\text { 9W LED } \\
\text { Bulb }\end{array}$ & $10,000 \mathrm{~h}$ & 78.6 L.E. & 52,741 L.E. \\
\hline 9067 & $\begin{array}{l}14 \mathrm{~W} \\
600 \mathrm{~mm} \\
\text { fluorescent }\end{array}$ & $\begin{array}{l}8 \mathrm{~W} \\
600 \mathrm{~mm} \\
\text { LED }\end{array}$ & $30,000 \mathrm{~h}$ & 176.8 L.E. & 1,603,046 L.E. \\
\hline 674 & $28 \mathrm{~W}$ & $14.5 \mathrm{~W}$ & $30,000 \mathrm{~h}$ & 206.25 L.E. & 139,013 L.E. \\
\hline
\end{tabular}




\begin{tabular}{|l|l|l|l|l|}
\hline & $\begin{array}{l}1200 \mathrm{~mm} \\
\text { fluorescent }\end{array}$ & $\begin{array}{l}1200 \mathrm{~mm} \\
\text { LED }\end{array}$ & & \\
\hline & \multicolumn{2}{|l|}{ Total replacement cost } & $1,794,800$ L.E. \\
\hline
\end{tabular}

\subsection{PV panels adding cost}

The available areas on the site to install solar panels were $5,616 \mathrm{~m}^{2}$. The solar panels selected to be at height $3.5 \mathrm{~m}$ from the floor to avoid any obstructions and gain all the useful areas. According to the simulation, the solar panels plant produces $1,296,191 \mathrm{kWh} / \mathrm{a}$ from these areas. The survey in the local market result present that the $10 \mathrm{~m}^{2}$ from the solar panels area cost from 16,000 to 18,000 L.E. Including solar panels, inverters, metal framing, installation and full accessories. By taking the average cost in the local market 17,000 L.E. Total electric panels station with area of $5,600 \mathrm{~m}^{2}$ has cost of 9,520,000 L.E. The station lifetime is 20 years according to the local supplier. The operating and maintenance costs are assumed to be $1.5 \%$ annually from the capital cost. So, the total cost for PV panels is 10,355,516 L.E.

\subsection{Payback Period or Return on Investment}

The return on investment could be estimated in 2 cases. The first one is by applying all the passive retrofit energy efficiency measures without installing the PV panel stations. The saved energy cost is compared with the investment cost to calculate the payback period due to implementation. The second case will be the modifications in addition to the PV panel station. Also, with comparing this case investment with the electricity cost and calculating the payback period using Egypt tariff framework over 2019. The cost per $\mathrm{kWh} 1.60 \mathrm{L.E}$. as per the monthly consumption is more than $1000 \mathrm{kWh} /$ month as per the simulation results.

In the first case the overall cost due to implementing glazing, shading and lighting is 3,009,924 L.E. The electricity consumption saving is $597,470 \mathrm{kWh} / \mathrm{a}$ with cost of 955,952 L.E/a. The total cost of implemented energy efficiency measures requires 3.15 years ( 3 years \& 1.78 month) to return the investment.

In the second case the overall cost of installing the PV system is 13,365,440 L.E. The electricity consumption saving is $1,896,904 \mathrm{kWh} / \mathrm{a}$ with cost of $3,035,046.4$ L.E/a. The total cost of implemented PV system requires 4.61 years (4 years \& 4.8 month) to return the investment.

\section{Conclusion}

- By starting with the change in the building orientation, we could find the base model case is the lowest energy consumption $\left(279.955 \mathrm{kWh} / \mathrm{m}^{2}\right.$. a). The $90^{\circ}$ building rotation is the highest energy consumption $\left(282.308 \mathrm{kWh} / \mathrm{m}^{2}\right.$. a). There is no energy reduction done by rotating the building. 
- By adding 3 thicknesses of insulation to change the U-Value from 0.28 $\mathrm{W} / \mathrm{m}^{2}$. $\mathrm{K}$ to $0.2,0.19$ and $0.18 \mathrm{~W} / \mathrm{m}^{2}$. $\mathrm{K}$. The lowest $\mathrm{U}$-Value which gave the lowest energy consumption $\left(279.396 \mathrm{kWh} / \mathrm{m}^{2}\right.$. a) compared to the base case consumption $\left(279.955 \mathrm{kWh} / \mathrm{m}^{2}\right.$. a) but the saving was too little.

- Different glazing types were applied to the building instead of the base case glazing and type-07 was the lowest energy consumption $\left(268.525 \mathrm{kWh} / \mathrm{m}^{2}\right.$. a) with energy reduction $4 \%$ comparing to the base case $\left(279.955 \mathrm{kWh} / \mathrm{m}^{2}\right.$. a).

- Due to adding shading to the façade windows, the energy reduction percentage was less than $1 \%$ with different projection factors in north, east and west directions. In south directions varies from $1.15 \%$ to $2.11 \%$ and in all directions $\left(270.913 \mathrm{kWh} / \mathrm{m}^{2}\right.$. a) achieved $3.23 \%$ energy reduction.

- After applying 3 types of fixtures incandescent, CFL \& LED fixtures. The LED fixtures gave the lowest energy consumption $\left(253.813 \mathrm{kWh} / \mathrm{m}^{2}\right.$. a). The lighting load individually decreased by $43.8 \%$ and the total consumption decreased by $9.4 \%$.

- The optimized model properties were selected to achieve the lowest energy consumption $\left(176.518 \mathrm{kWh} / \mathrm{m}^{2}\right.$. a) which was $11.925 \%$ reduction in energy consumption.

- After applying renewable energy source (photovoltaic panels), the net energy consumption reduced to $\left(124.541 \mathrm{kWh} / \mathrm{m}^{2}\right.$. a) with $29.45 \%$ reduction percentage.

- Achieving net zero energy building requires 3.37 times of building floor area.

- The life cycle cost analysis was done on 2 stages. The first one was with applying all the modifications without the PV panels. Estimating the capital and running costs compared with the energy conservation and estimating the payback period ( 3 years \& 1.78 month). The second stage was after applying PV panels (4 years \& 4.8 month).

\section{References}

[1] Eehc. EGYPTIAN ELECTRICITY HOLDING COMPANY ANNUAL REPORT 2017 / 2018. 2018.

[2] Hanna GB. Energy Efficient Residential Building Code for Arab Countries. 10th Int Conf Enhanc Build Oper 2010:1-7.

[3] Hanna GB, Physicist B. Energy Standard for New Hotel Buildings in Egypt. Renew Energy 2006;4:19-25.

[4] Shamseldin AKM. Compatibility of global environmental assessment methods of buildings with an Egyptian energy code. HBRC J 2017;13:72-82. doi:10.1016/j.hbrcj.2015.04.002.

[5] Elrefaei H, Khalifa MA. NATURAL RESOURCES AND DEVELOPMENT A critical review on the National energy efficiency action plan of Egypt 2014:18-24. doi:10.5027/jnrd.v4i0.03. 
[6] Hanna GB. Energy Efficiency Building Codes and Green Pyramid Rating System. Int J Sci Res 2015;4:3055-60.

[7] Elharidi A, Tuohy P, Teamah M. Facing the Growing Problem of the Electric Power Consumption in Egyptian Residential Building Using Building Performance Simulation Program. Build Simul Cairo 2013 - Towar Sustain Green Built Environ 2013.

[8] Attia S, Gratia E, Herde A De, Jan LM. Tool for Design Descision Making: Zero Energy Residential Buildings in Hot Humid Climate 2012;4:3720-7.

[9] Aldali KM, Moustafa WS. An attempt to achieve efficient energy design for High-Income Houses in Egypt: Case Study: Madenaty City. Int J Sustain Built Environ 2016;5:334-44. doi:10.1016/j.ijsbe.2016.04.007.

[10] Paper C. Impacts of Changing Facades Configurations on Office Building Energy Consumption in Hot Arid Climates Impacts of Changing Facades Configurations on Office Building Energy Consumption in Hot Arid Climates 2015.

[11] El-Darwish I, Gomaa M. Retrofitting strategy for building envelopes to achieve energy efficiency. Alexandria Eng J 2017:1-11. doi:10.1016/j.aej.2017.05.011.

[12] Reda F, Tuominen P, Hedman ^, Ibrahim MGE. Low-energy residential buildings in New Borg El Arab: Simulation and survey based energy assessment. Energy Build 2015;93:65-82. doi:10.1016/j.enbuild.2015.02.021.

[13] Diab F, Lan H, Zhang L, Ali S. An environmentally-friendly tourist village in Egypt based on a hybrid renewable energy system-Part two: A net zero energy tourist village. Energies 2015;8:6945-61. doi:10.3390/en8076945.

[14] Albadry S, Tarabieh K, Sewilam H. Achieving Net Zero-Energy Buildings through Retrofitting Existing Residential Buildings Using PV Panels. Energy Procedia 2017;115:195-204. doi:10.1016/j.egypro.2017.05.018.

[15] Moving Towards Net-Zero Energy of Existing Building in Hot Climate 2012.

[16] Alrashed F, Asif M. Prospects of renewable energy to promote zero-energy residential buildings in the KSA. Energy Procedia 2012;18:1096-105. doi:10.1016/j.egypro.2012.05.124.

[17] AlAjmi A, Abou-Ziyan H, Ghoneim A. Achieving annual and monthly netzero energy of existing building in hot climate. Appl Energy 2016;165:51121. doi:10.1016/j.apenergy.2015.11.073.

[18] Ghoneim AA. Achieving Net Zero Energy Building in a Hot Climate Using Integrated Photovoltaic and Parabolic trough Collectors 2015;9:1092-8.

[19] M. Nassief M. Evaluation of Electricity Consumption of a Residential Flat in Egypt. Am J Electr Power Energy Syst 2014;3:37. doi:10.11648/j.epes.20140302.14.

[20] Kraus M, Konecn\&\#253; F. The evaluation of nearly zero energy buildings in the Czech Republic. Adv Mater Res 2013;649:15-8. doi:10.4028/www.scientific.net/AMR.649.15.

[21] Deng S, Wang RZ, Dai YJ. How to evaluate performance of net zero energy building - A literature research. Energy 2014;71:1-16. 
doi:10.1016/j.energy.2014.05.007.

[22] Mpmar.gov.eg. Sustainable development starategy (Egypt vision 2030). n.d.

[23] Guglielmetti R, Macumber D, Long N. Openstudio: An open source integrated analysis platform. Proc Build Simul 2011 12th Conf Int Build Perform Simul Assoc 2011:442-9.

[24] Raslan R, Mavrogianni A. Developing a National Stock Model to Support Building Energy Efficiency Research and Policy in Egypt. Build Simul Cairo 2013.

[25] American Society of Heating Refrigerating and Air Conditioning Engineers (ASHRAE). Chapter 18 - Nonresidetial Cooling and Heating Load Calculaitions. ASHRAE Handbook-Fundamentals (SI) 2013:18.1-18.62.

[26] Schwedler MCA, Hydeman MM, Hanson SS, Skalko S V, Heinisch R V, Heminger NB, et al. ASHRAE STANDARD Energy Standard for Buildings Except Low-Rise Residential Buildings 2010;2007:209-11.

[27] Brackney, L., Parker, A., Macumber, D., Benne K. Building Energy Modeling with OpenStudio. Springer International Publishing; 2018.

[28] Danks RA, Muller C, Hedrick RL, Fisher FJ, Osborn JE, Butler DS, et al. Ventilation for acceptable indoor air quality. ASHRAE Stand 2007;2007:141.

[29] Elhadad S, Baranyai B, Gyergyák J. The impact of building orientation on energy performance: A case study in New Minia, Egypt. Pollack Period 2018;13:31-40. doi:10.1556/606.2018.13.3.4.

[30] HBRC. Egyptian code for the bases of design and conditions for the implementation of lighting works. 2006.

[31] Fuller SK, Petersen SR. Life-Cycle Costing Manual for the Federal Energy Management Program. NIST Handb 135 1996:1-222. doi:10.1108/eb006413.

[32] Annual Inflation Rate 2019.

https://www.capmas.gov.eg/Pages/IndicatorsPage.aspx?page_id=6124\&ind_i $\mathrm{d}=1202$.

[33] Central Bank of Egypt Statistics 2019.

https://www.cbe.org.eg/en/Economicresearch/Statistics/Pages/TimeSeries.asp $\mathrm{x}$.

\section{Appendix}

The building is in. The average monthly weather properties were used for Cairo/ Egypt, like total radiation, relative humidity and dry bulb temperature are as mentioned in Table A-1. Also, it is shown in Figure A-1, Figure A-2 \& Figure A-3. 
Table A-1 Cairo weather data (https://energyplus.net/weatherlocation/africa_wmo_region_1/EGY//EGY_Cairo.623660_IWEC).

\begin{tabular}{|l|c|c|c|}
\hline \multicolumn{1}{|c|}{ Month } & $\begin{array}{c}\text { Total Radiation } \\
\left(\mathrm{kWh} / \mathrm{m}^{2}\right)\end{array}$ & $\begin{array}{c}\text { Average Relative } \\
\text { Humidity }(\%)\end{array}$ & $\begin{array}{c}\text { Average Dry Bulb } \\
\text { Temperature }\left({ }^{\circ} \mathrm{C}\right)\end{array}$ \\
\hline January & 164 & 56 & 15 \\
\hline February & 169 & 60 & 16 \\
\hline March & 206 & 53 & 22 \\
\hline April & 215 & 49 & 26 \\
\hline May & 223 & 44 & 28 \\
\hline June & 216 & 52 & 29 \\
\hline July & 211 & 56 & 30 \\
\hline August & 202 & 59 & 28 \\
\hline September & 197 & 57 & 25 \\
\hline October & 185 & 58 & 20 \\
\hline November & 154 & 61 & 15 \\
\hline December & 156 & 62 & 19 \\
\hline
\end{tabular}

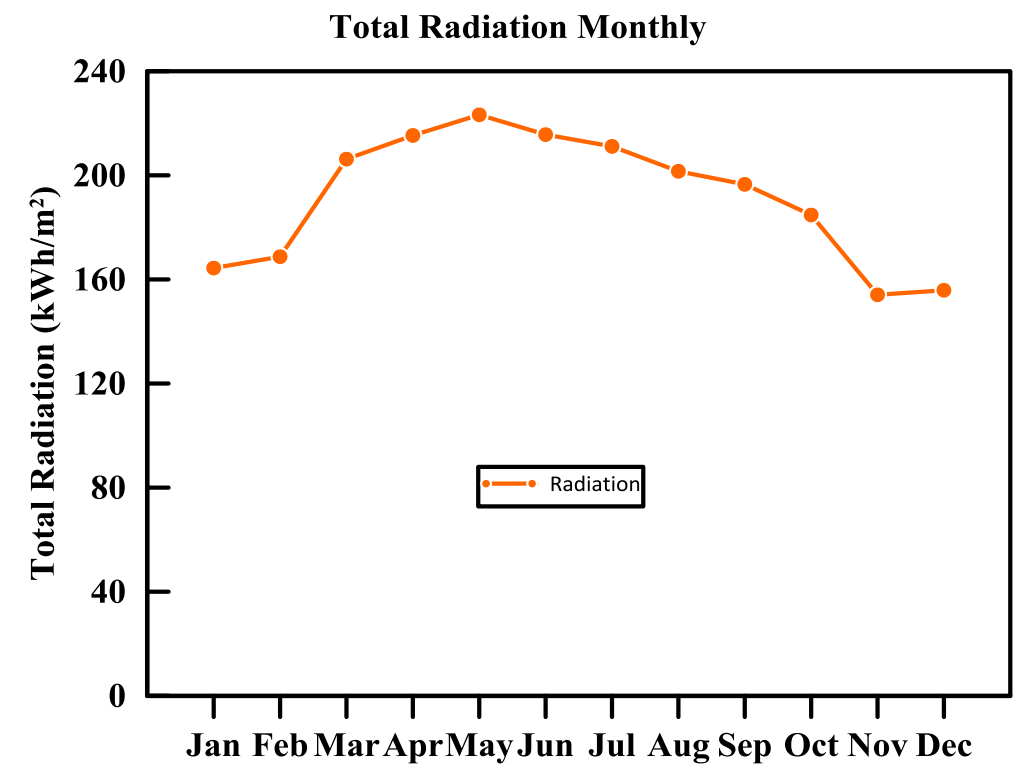

Figure A-1 Total Monthly Radiation 


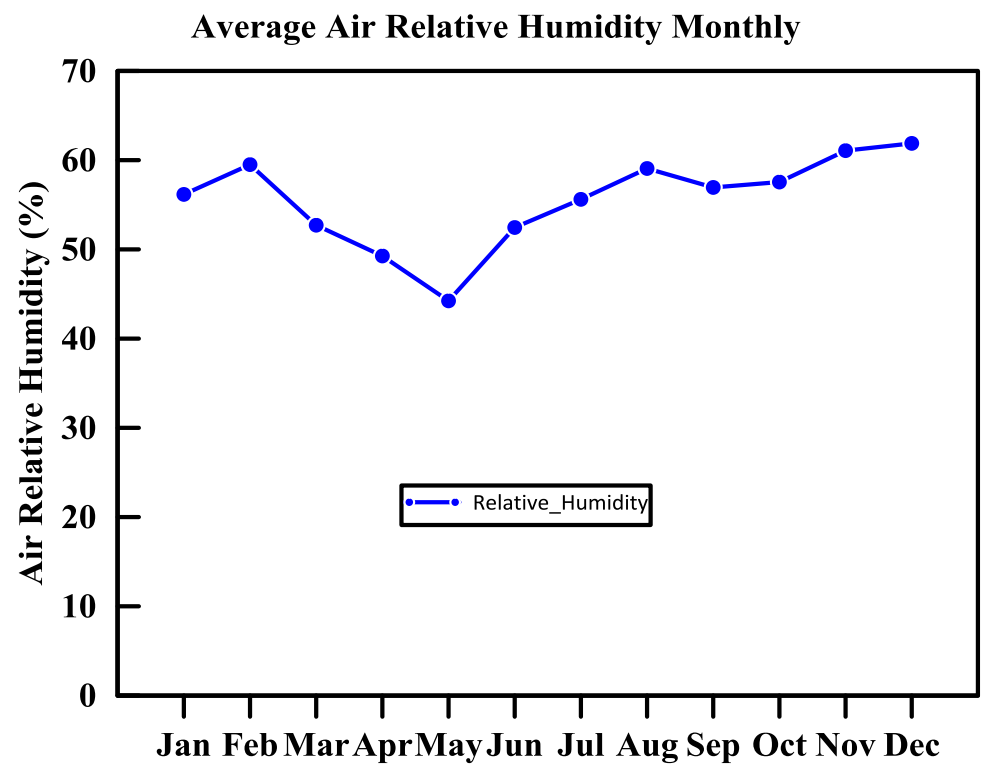

Figure A-2 Average Air Relative Humidity Monthly

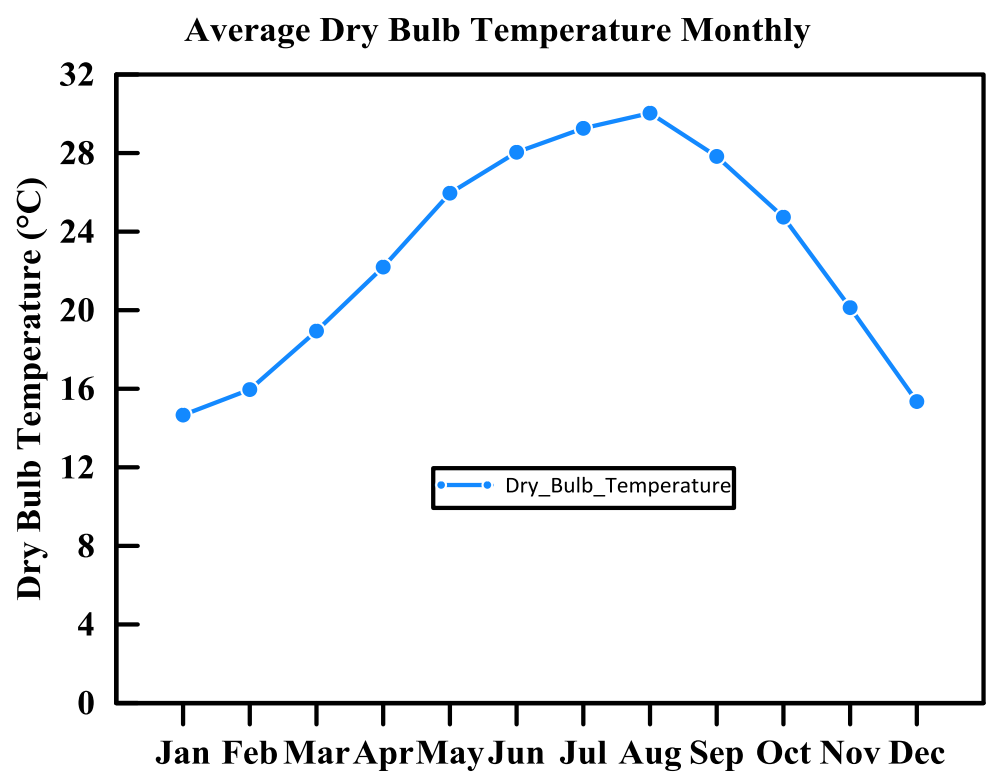

Figure A-3 Average Dry Bulb Temperature Monthly 